\title{
Selenium Enrichment of Horticultural Crops
}

\author{
Martina Puccinelli ${ }^{1}$, Fernando Malorgio ${ }^{1}$ and Beatrice Pezzarossa ${ }^{2, *}$ \\ 1 Department of Agriculture, Food and Environment, University of Pisa, via del Borghetto 80, 56124 Pisa, \\ Italy; martina.puccinelli@for.unipi.it (M.P.); fernando.malorgio@unipi.it (F.M.) \\ 2 Institute of Ecosystem Study, CNR, via Moruzzi 1, 56124 Pisa, Italy \\ * Correspondence: beatrice.pezzarossa@ise.cnr.it; Tel.: +39-050-6212488; Fax: +39-050-6212473
}

Academic Editors: Claudio Santi and Luana Bagnoli

Received: 9 May 2017; Accepted: 31 May 2017; Published: 4 June 2017

\begin{abstract}
The ability of some crops to accumulate selenium (Se) is crucial for human nutrition and health. Selenium has been identified as a cofactor of the enzyme glutathione peroxidase, which is a catalyzer in the reduction of peroxides that can damage cells and tissues, and can act as an antioxidant. Plants are the first link in the food chain, which ends with humans. Increasing the Se quantity in plant products, including leafy and fruity vegetables, and fruit crops, without exceeding the toxic threshold, is thus a good way to increase animal and human Se intake, with positive effects on long-term health. In many Se-enriched plants, most Se is in its major organic form. Given that this form is more available to humans and more efficient in increasing the selenium content than inorganic forms, the consumption of Se-enriched plants appears to be beneficial. An antioxidant effect of Se has been detected in Se-enriched vegetables and fruit crops due to an improved antioxidative status and to a reduced biosynthesis of ethylene, which is the hormone with a primary role in plant senescence and fruit ripening. This thus highlights the possible positive effect of Se in preserving a longer shelf-life and longer-lasting quality.
\end{abstract}

Keywords: biofortification; antioxidant; plant senescence; post-harvest

\section{Introduction}

\subsection{Selenium in Animals and Humans}

Selenium (Se) is an essential component of selenoaminoacids and selenoproteins. It thus has multiple roles in the growth and functioning of living cells and has many crucial biological functions in animals and humans [1,2]. Selenium is also a cofactor of the enzyme glutathione peroxidase, and a catalyzer of the reduction of peroxides, which can damage cells and tissues [3]. It is thus involved in antioxidant defense [4]. As a component of iodothyronine deiodonase and thioredoxin reductase [5,6], Se is involved in the formation of thyroid hormones. Selenium plays a role in DNA synthesis, fertility, reproduction, and in muscle function by improving endurance and recovery, and slowing the ageing process $[7,8]$. Se also helps prevent certain cancers and reduces the incidence of viral infections, cardiovascular damage, arthritis, and altered immunological functions $[9,10]$.

Se is biologically active at low concentrations for normal growth and development, and at moderate concentrations for homeostatic function. However, at high concentrations, Se can induce toxicity [11]. The margin between the nutritional requirement and toxicity is quite small, and outside this range, deficiency or toxicity can occur. The Food and Nutrition Board of the Institute of Medicine (USA) has proposed a Recommended Dietary Allowance (RDA) of $55 \mu \mathrm{g} \mathrm{Se} \mathrm{day}^{-1}$ for adults and a tolerable upper intake of $400 \mu \mathrm{g}$ Se day ${ }^{-1}$ [12].

Sub-optimal Se intake and status are correlated with a wide variety of human diseases, such as heart diseases, cystic fibrosis, cognitive decline, Alzheimer's, cancer, impairment in immune function, 
oxidative stress-related disorders, reduced fertility and hypothyroidism [10,13]. A severe Se deficiency, caused by a Se intake lower than $10 \mu \mathrm{g}$ Se day ${ }^{-1}$, may be associated with a cardiomyopathy called Keshan disease, and with an endemic degenerative osteoarthritis known as Kashin-Beck disease [1].

On the other hand, the short-term ingestion of high levels of Se can cause nausea, vomiting and diarrhea. If the excessive consumption is chronic, it may lead to a specific disease called selenosis, and also damage the cardiovascular, gastrointestinal, neurological and hematopoietic systems [14-16]. Selenosis has been observed in populations exposed to high levels of dietary selenium and is associated with the consumption of high-Se crops grown on seleniferous soils. Symptoms of selenosis include hair loss, brittle hair, thickened and stratified nails, gastrointestinal disturbances, and garlic odor from breath and skin. The USA Environmental Protection Agency estimated the average dietary intake at which clinical selenosis appears as $1262 \mu \mathrm{g}$ Se day ${ }^{-1}$.

\subsection{Selenium in Plants}

There is no definitive evidence regarding whether selenium is essential for vascular plants However, it has been hypothesized that it may have beneficial biological functions in species that are able to accumulate high amounts of Se and that need Se for their normal growth [17-19]. The accumulation of selenium in plants varies in relation to plant species, and is affected by soil Se concentration, soil properties and the chemical form of Se [20,21].

The leaf Se concentration in most plants, defined as non-accumulators, is usually below $100 \mathrm{mg}$ Se $\mathrm{kg}^{-1}$ dry weight. Only a selected number of plant species grown in areas rich in selenium can accumulate a high amount of selenium in the leaves. These plants are classified as hyperaccumulators when they accumulate more than $1000 \mathrm{mg} \mathrm{kg}^{-1}$ dry weight (Astralagus and Stanleya pinnata), and indicators or secondary accumulators when they accumulate $100-1000 \mathrm{mg} \mathrm{kg}^{-1}$ dry weight (Brassica juncea, Melilotus, Atriplex) [22].

Most agricultural crops have a much lower tolerance $\left(<50 \mathrm{mg} \mathrm{Se} \mathrm{kg}^{-1}\right)$, however Brassicaceae, onion, garlic and some mushrooms have a high Se concentration due to their high content of sulfur compounds. Selenium has a close similarity in terms of properties to sulfur and it can play the same role as S in biochemical systems. Uptake, translocation and metabolism of Se mimics those of $\mathrm{S}$, thus the substitution of sulfur with selenium results in selenium analogue compounds that increase the selenium content $[18,23,24]$. Legumes, especially lentils [25], contain a high Se concentration, however nuts rich in proteins, such as pistachios, walnuts and Brazil nuts, have been found to have the richest selenium content. Fruits usually contain a low selenium content, probably due to the low protein and high-water content [26].

At appropriate concentrations, Se positively affects seed germination and plant growth [17,27-29]. Se protects plants from several abiotic stresses, including ultraviolet light, heavy metals and arsenic, and biotic stress, including pathogens and herbivores [30]. Se counteracts oxidative stress by inhibiting lipid peroxidation [19,31], and increases gluthatione peroxidase (GSH-Px) activity [27,32,33]. The enhanced antioxidation associated with an increase in glutathione peroxidase activity may delay plant senescence and decrease postharvest losses.

At high concentrations, Se acts as a pro-oxidant, inhibiting the growth and germination of seeds and reducing yields $[17,27,34]$.

Selenium can affect the quality of vegetables and fruit. An increased cellular content of linoleic acid and sterols and a decreased oleic acid content have been observed in Camelia oleifera plants treated with selenium [35]. Se treatment had a positive effect on maintaining the sensory and the postharvest quality by reducing the respiratory intensity and ethylene production in broccoli [36], by decreasing phenylalanine ammonia-lyase (PAL) activity and ethylene production in lettuce and chicory [37], and by diminishing ethylene production in tomatoes $[38,39]$. In green tea, Se increased plant yield, total amino acid, and vitamin C content [28]. In peaches and pears, Se spraying of the canopy slowed down the rate of fruit softening, and thus increased the shelf-life [40]. The application of selenium may be effective in controlling postharvest gray mold disease in tomato fruits caused by Botritis cinerea [41]. 
Due to its ability to increase the antioxidant defense of plants $[18,42,43]$, Se has been found to delay plant senescence $[17,27,37]$ and fruit ripening $[39,40,44,45]$ in several horticultural species, which could lead to decreased postharvest loss. The antioxidant capacity of Se and improved gluthatione peroxidase activity are related $[17,19,27]$, which suggests the presence of a Se-dependent GSH-Px [17].

\section{Selenium Enrichment of Agricultural Crops}

Several strategies can improve a suboptimal selenium status, including a diversified diet, food supplements, fortification of foodstuffs, and the biofortification of plants [46-50].

A diversified diet can provide a good intake of minerals, proteins and vitamins, however in many socio-economic contexts around the world, access to diverse diets is not possible [50-54].

Se supplements include sodium selenate and sodium selenite (inorganic forms), and selenium-enriched yeast, selenomethionine and selenocysteine (organic forms). However, since 2002 in the EU only inorganic forms of selenium are permissible as food supplements. Se-enriched yeast appears to have a high variability with respect to its Se content and speciation, but represents a good way to increase the consumption of Se by humans [46].

The addition of nutrients, such as minerals and vitamins, to increase the nutritional quality of processed food is called fortification [55,56]. It is practiced to restore nutrients lost during food processing or in areas characterized by problems of malnutrition and aimed at correcting deficiencies in one or more nutrients.

Increasing the concentration of micronutrient in plants in order to improve the nutritional quality of plant-based food during plant growth rather than during crop processing is known as biofortification [57-60].

The ability of some crops to accumulate selenium is crucial for human nutrition and health. Plants are the first link in the food chain which ends with humans. Increasing the Se content in plant products, including leafy and fruity vegetables, fruit crops, and cereals, without exceeding the toxic threshold, is thus a good way to increase animal and human Se intake and may have positive effects on long-term health.

The main strategies to increase both mineral levels and their bioavailability in the edible part of staple crops include agronomic intervention and plant breeding.

Agronomic biofortification is performed through the application of mineral elements with a good mobility, such as I, Zn, and Se, in the soil and in the plants [58,61-63]. This strategy has mainly been conducted in Northern and Central Europe and at a national scale was adopted in Finland in 1984, where Se was added to all agricultural fertilizers because of the very low consumption of Se by Finnish people. The program was successful in increasing Se concentration in foodstuffs and Se intake in humans $[48,64]$. Se biofortification programs under Mediterranean conditions may include legumes, which constitute the main source of dietary proteins for a large share of the world's population and can accumulate a higher amount of Se in the grain compared to cereals. In peas, the application of a small quantity of sodium selenate resulted in a great increase in Se concentration in the grain [65].

Se biofortification of fruits, vegetables and cereals is a good way to increase the supplementation of selenium by humans and has been reviewed elsewhere [30,48,62,66-68]. In many Se-enriched plants most $\mathrm{Se}$ is in the major organic form (selenomethionine, selenocysteine and methylselenocysteine). It is more available to humans and more efficient in increasing the selenium content, especially in the blood, than the inorganic forms. The consumption of Se-enriched plants thus appears to be beneficial $[47,48,69,70]$. For example, in onions, garlic and broccoli, Se is mostly present as Se-methylselenocysteine or $\gamma$-glutamyl-Se-methylselenocysteine, with some differences according to the plant species and application doses. In Se-enriched onions the main Se chemical form is $\gamma$-glutamyl-Se-methylselenocysteine (about $63 \%$ of total Se), followed by selenate $(10 \%)$, and selenomethionine (5\%) [71,72]. $\gamma$-glutamyl-Se-methylselenocysteine is the predominant Se species $(73 \%)$ which can also be found in enriched garlic. Other chemical species are present at lower concentrations: seleniomethinine (13\%), $\gamma$-glutamyl-selenomethionine $(4 \%)$, Se-methylselenocysteine 
(3\%) and selenate (2\%) [73]. In Se-enriched broccoli Se mostly consists of Se-methylselenocysteine $(45 \%)$ and small amounts of selenomethionine and selenate [74].

The potential of Se fortification of crops by genetic manipulation is still not clear. Some evidence indicates that Se content can be increased in grains [59,63,64,67] and lentils [25] by breading, thus providing an alternative to agronomic fortification and minimizing the use of Se fertilizers, however further efforts are needed.

Possible negative effects of selenium enrichment to plants are mainly caused by interference with sulfur metabolism, since Se is incorporated into organic compounds which can act as Se analogues (selenocysteine and selenomethionine) of essential S compounds (cysteine and methionine) [18].

The amount and the chemical form of Se found in natural products is well known, and the main foods providing selenium in the diet are nuts, bread, cereals, meat, fish, eggs, and milk/dairy products, as reviewed by Fairweather-Tait et al. [50].

The accumulation of selenium in food crops induced by biofortification must satisfy a rational approach to selenium supplementation according to the recommended RDA, without leading to Se intoxication and without producing phytotoxic effects or reducing the agricultural production.

\section{Selenium Supplementation in Plants}

There are four main methods for enriching plants with selenium: (1) adding Se to the soil; (2) soaking seeds in a Se solution before sowing; (3) foliar or fruit spraying; and (4) hydroponic cultivation with a nutrient solution containing Se.

The addition of Se fertilizers to the soil is an appropriate way to biofortify high amounts of foodstuffs and to increase the Se content in soils that have a low selenium content [61,75-78]. However, high amounts of Se need to be applied to the soil to obtain Se plant concentrations equal to other fertilization methods [49,79]. The soil selenium content can be increased by fertilizing soil with salt (selenate or selenite) [61] or by the incorporation of Se-hyperaccumulator plants in the soil. Good results in the biofortification of carrots and broccoli have been obtained by adding Se-enriched Stanleya pinnata plants to soil [80]. As a Se-hyperaccumulator, Stanleya pinnata can be used for the phytoremediation of soil with a high concentration of Se [81], and the Se-enriched plant material can then be incorporated into the soil thus combining phytoremediation and biofortification [82].

Selenium spraying has been used to enhance the Se content in potatoes [83], rice [84], soybeans [85], buckwheat and pumpkins [86], garlic [87], carrots [88], broccoli [89], cabbages [76], radishes [90], basil [91-94], tomatoes [44,95], peaches and pears [40], and grapes [96]. Results of spraying depend on the characteristics of the leaf and fruit surface, such as the presence of hairs, the characteristics of the epicarp, the chemical composition of the epicuticular wax, or the deposition of wax platelets [40]. Foliar application of Se has proven effective for the biofortification of Chicorium intybus L. plants: Se concentrations in sprayed plants [97] were found to be higher compared with plants grown in a nutrient solution containing Se $[37,98]$. In addition, foliar spraying is preferable to soil application due to the lower amount of Se generally used, and because no residual effects have been observed. Foliar application involves a minimum consumption of Se salts and is an effective, safe and economically acceptable way of improving Se content in crops [99].

The results of biofortifying plants by soaking seeds in a solution containing Se are still not well known, however good results have been obtained in grains. Ožbolt et al. [100] found an increased Se content in buckwheat plants without any decrease in production, and an improvement in drought tolerance was found by Nawaz et al. [101] in wheat. However, Se concentrations detected in these biofortified plants were lower compared to the other methods.

Hydroponic culture enriched with selenium is useful for providing Se-enriched vegetables. Studies have been conducted on lettuce [27,34,37,102,103], sweet basil [91], chicory [37], spinach [104], chard [105] and tomatoes [34,39]. The use of a floating system makes it possible to control the concentration of Se in the growth medium and to easily adapt the Se supply to the growth stage of plants, thus avoiding salt loss [37]. 
In general, the supplementation of Se by foliar application or in the growth medium increases Se concentration in plant tissues without a loss of production or qualitative characteristics.

\section{Selenium Enrichment of Leafy Vegetable: Effects on Yield, Quality and Senescence}

Se biofortification of leafy vegetables has been widely studied. Plants have been grown on selenium-enriched substrates [106-109], in a nutrient solution with selenium added $[37,98,104,105,110-116]$ or treated with Se foliar application [91-94,97,117]. Table 1 summarizes the various studies on the Se enrichment of leafy vegetables. 
Table 1. Selenium (Se) accumulation in the edible parts of leafy vegetables in relation to the concentration, the chemical form of Se supplemented to plants, and the method of Se supplementation.

\begin{tabular}{|c|c|c|c|c|c|}
\hline Plant Species & [Se] Supplemented & Se Chemical Form & $\begin{array}{l}\text { Se Supplementation } \\
\text { Methods }\end{array}$ & [Se] In the Edible Part & Reference \\
\hline Lactuca sativa L. var. Acephala & 0.5 and $1 \mathrm{mg} \mathrm{Se} \mathrm{L}^{-1}$ & selenate & $\begin{array}{l}\text { Enrichment of } \\
\text { nutrient solution }\end{array}$ & $\begin{array}{l}26 \mathrm{mg} \mathrm{kg}^{-1} \text { dry weight } \\
\text { (DW) }\end{array}$ & Diaz et al. [98] \\
\hline Lactuca sativa L. var. Acephala & 1.5 and $5 \mathrm{mg} \mathrm{Se} \mathrm{kg}^{-1}$ & selenite & Soil fertilization & $20 \mathrm{mg} \mathrm{kg}^{-1} \mathrm{DW}$ & Pezzarossa et al. [108] \\
\hline Lactuca sativa $\mathrm{L}$. & $5 \mathrm{mg} \mathrm{Se} \mathrm{kg}^{-1}$ & selenate & Soil fertilization & $170 \mathrm{mg} \mathrm{kg}^{-1} \mathrm{DW}$ & Pezzarossa et al. [108] \\
\hline Lactuca sativa L. var. Acephala & 0.5 and $1 \mathrm{mg} \mathrm{Se} \mathrm{L}^{-1}$ & selenate & $\begin{array}{l}\text { Enrichment of } \\
\text { nutrient solution }\end{array}$ & $26 \mathrm{mg} \mathrm{kg}^{-1} \mathrm{DW}$ & Malorgio et al. [37] \\
\hline Lactuca sativa & 0.16 to $5.12 \mathrm{mg} \mathrm{Se} \mathrm{L}^{-1}$ & selenate & $\begin{array}{l}\text { Enrichment of } \\
\text { nutrient solution }\end{array}$ & 10 to $43.3 \mathrm{DW}$ & $\begin{array}{c}\text { Rios et al.; Malorgio et al.; Ramos et al.; } \\
\text { Hawrylak-Nowak } \\
{[37,102,111,113,114,116,118]}\end{array}$ \\
\hline Lactuca sativa L. cv. Justyna & from 0.16 to $2.4 \mathrm{mg} \mathrm{Se} \mathrm{L}^{-1}$ & selenite & Nutrient solution & $30.6 \mathrm{mg} \mathrm{kg}^{-1} \mathrm{DW}$ & Hawrylak-Nowak [116] \\
\hline Lactuca sativa $\mathrm{L}$. & 1 to $1000 \mathrm{mg} \mathrm{Se} \mathrm{kg}-1$ & selenate & Peat fertilization & $219 \mathrm{mg} \mathrm{kg}^{-1} \mathrm{DW}$ & Businelli et al. [109] \\
\hline Lactuca sativa L. cv. Capitata & $40 \mu \mathrm{g} \mathrm{plant}^{-1}$ & $\begin{array}{l}\text { selenite, selenium urea, } \\
\text { imidoselenocarbamate }\end{array}$ & $\begin{array}{l}\text { Vermiculite-sand-peat } \\
\text { fertilization }\end{array}$ & 68.4 to $413.5 \mu \mathrm{g} \mathrm{kg}^{-1} \mathrm{DW}$ & $\begin{array}{l}\text { Goicoechea et al.; Sanmartín et al. } \\
{[106,107]}\end{array}$ \\
\hline Chicorium intybus L. & 0.5 and $1 \mathrm{mg} \mathrm{Se} \mathrm{L}^{-1}$ & selenate & $\begin{array}{l}\text { Enrichment of } \\
\text { nutrient solution }\end{array}$ & $30 \mathrm{mg} \mathrm{kg}^{-1} \mathrm{DW}$ & Diaz et al. [98] \\
\hline Chicorium intybus L. & $1 \mathrm{mg} \mathrm{Se} \mathrm{L}^{-1}$ & selenate & Foliar fertilization & $45 \mathrm{mg} \mathrm{kg}^{-1} \mathrm{DW}$ & Germ et al. [97] \\
\hline Chicorium intybus $\mathrm{L}$. & 0.5 and $1 \mathrm{mg} \mathrm{Se} \mathrm{L}^{-1}$ & selenate & $\begin{array}{l}\text { Enrichment of } \\
\text { nutrient solution }\end{array}$ & $29.1 \mathrm{mg} \mathrm{kg}^{-1} \mathrm{DW}$ & Malorgio et al. [37] \\
\hline Ocimum basilicum $\mathrm{L}$. & 1 to $50 \mathrm{mg} \mathrm{Se} \mathrm{L}^{-1}$ & selenate & Foliar fertilization & 7.86 to $150 \mathrm{mg} \mathrm{kg}^{-1} \mathrm{DW}$ & $\begin{array}{c}\text { Hawrylak-Nowak; Kopsell et al.; } \\
\text { Barátová et al. [91-93] }\end{array}$ \\
\hline Ocimum basilicum $\mathrm{L}$. & 25 and $50 \mathrm{mg} \mathrm{m}^{-2}$ & selenate & Foliar fertilization & $7.86 \mathrm{mg} \mathrm{kg}^{-1} \mathrm{DW}$ & Mezeyová et al. [94] \\
\hline Ocimum basilicum $\mathrm{L}$. & 2 to $32 \mathrm{mg} \mathrm{Se} \mathrm{L}^{-1}$ & selenite & Foliar application & $41.5 \mathrm{mg} \mathrm{kg}^{-1} \mathrm{DW}$ & Kopsell et al. [92] \\
\hline Spinacia oleracea $\mathrm{L}$. & 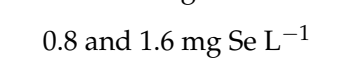 & selenate & $\begin{array}{l}\text { Enrichment of } \\
\text { nutrient solution }\end{array}$ & $\begin{array}{l}12 \mathrm{mg} \mathrm{kg}^{-1} \text { fresh weight } \\
\text { (FW) }\end{array}$ & Zhu et al. [110] \\
\hline Spinacia oleracea L. & 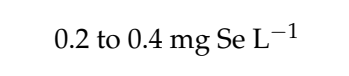 & selenate & $\begin{array}{l}\text { Enrichment of } \\
\text { nutrient solution }\end{array}$ & $15.5 \mathrm{mg} \mathrm{kg}^{-1} \mathrm{DW}$ & Ferrarese et al. [104] \\
\hline Spinacia oleracea $\mathrm{L}$. & 1 to $10 \mathrm{mg} \mathrm{Se} \mathrm{L}^{-1}$ & selenate & $\begin{array}{l}\text { Enrichment of } \\
\text { nutrient solution }\end{array}$ & $3.89 \mathrm{mg} \mathrm{g}^{-1} \mathrm{DW}$ & Saffaryazdi et al. [115] \\
\hline Beta vulgaris subsp. Vulgaris L. & 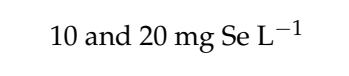 & selenate & $\begin{array}{l}\text { Enrichment of } \\
\text { nutrient solution }\end{array}$ & $1393 \mu \mathrm{g}$ of Se per shoot & Hernández-Castro et al. [105] \\
\hline
\end{tabular}


The addition of selenium has been found to significantly increase the Se content in plants, in general without negatively affecting the biomass and the quality of leaves, as in spinach [97,104,110,115,116], lettuce [102,106-108], basil [91,94], and chicory [37]. The addition of low doses of Se, of approximately $1.5 \mathrm{mg} \mathrm{Se} \mathrm{L}^{-1}$ in the nutrient solution $[37,102,104,108,110,115,116]$, or $1 \mathrm{mg} \mathrm{Se} \mathrm{L}^{-1}$ by foliar fertilization [97], were not found to induce toxic effects in chicory plants. Similarly, foliar fertilization with $50 \mathrm{mg} \mathrm{Se} \mathrm{L}^{-1}$ [91] or $25 \mathrm{mg} \mathrm{Se} \mathrm{m}^{-2}$ [94] did not negatively affect the biomass of sweet basil plants. Se could also have positive effects on plant growth, increasing yield in basil [91,117], chicory and lettuce $[37,98,102,116]$. Rios et al. [113] observed a positive effect of Se

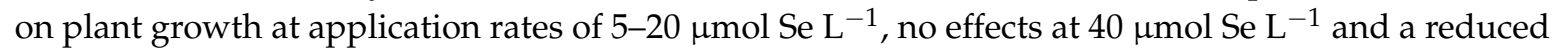

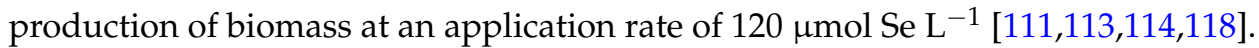

The chemical form of Se applied influences the toxicity in plants. In general, selenate is less toxic than selenite, and biomass production is higher when selenate is supplied [102,111,113-115,118]. In addition, selenite is toxic for plants at lower concentrations compared to selenate [102].

An antioxidant effect of Se has been detected in Se-enriched leafy vegetables due to the increase in the antioxidant enzyme activity: lypoxigenase (LOX) [113], superoxide dismutase (SOD) [102,111], catalase (CAT) [102], ascorbate peroxidase (APX), and glutathione peroxidase (GSH-Px) [111]. An improved oxidative state was also detected by measuring the content of some oxidative markers and compounds, such as malondialdehyde (MAD), 2,2-diphenyl-1-picrylhydrazyl (DPPH), $\mathrm{H}_{2} \mathrm{O}_{2}$, phenols and flavonoids, and by measuring the antioxidant activity by the Ferric Reducing Antioxidant Power (FRAP) assay. A reduction in DPPH, $\mathrm{H}_{2} \mathrm{O}_{2}$ [116], and MDA content [91], as well as an increase in antioxidant capacity (measured by the FRAP assay), phenols [91,106,113,115,117], and flavonoid content, were detected in plants treated with low concentrations of selenate [113].

The reduced glutathione content is also an indicator of the oxidative status of plant tissues, and Se increases the content of this compound [117]. However, sometimes Se does not induce changes in phenolic compound content [93,94], but it may have a positive effect on the anthocyanin content [91]. Due to its antioxidant action, Se may have a positive effect at low concentrations thus increasing plant growth. In contrast, at high concentrations Se, especially as selenite, can act as a pro-oxidant inducing oxidative stress in leafy vegetables, by increasing $\mathrm{H}_{2} \mathrm{O}_{2}[111]$, MDA $[113,116]$ content and lipid peroxidation [118].

The effect of Se on photosyntethic pigments is not clear. In general, low concentrations of Se have not been found to affect the photosynthetic pigment content in basil (treated with $50 \mathrm{mg}$ Se $\mathrm{L}^{-1}$ or lower) [91], lettuce (treated with $0.316 \mathrm{mg} \mathrm{Se} \mathrm{L}^{-1}$ selenite, $2.37 \mathrm{mg} \mathrm{Se} \mathrm{L}^{-1}$ selenate or lower) [116,118], and chicory ( $1 \mathrm{mg}$ Se $\mathrm{L}^{-1}$ or lower) [37]. On the other hand, higher concentrations of Se were found to decrease the content of photosynthetic pigments both in lettuce (treated with $0.474 \mathrm{mg} \mathrm{Se} \mathrm{L}^{-1}$ selenite, $3.16 \mathrm{mg} \mathrm{Se} \mathrm{L}^{-1}$ selenate or higher [116], $40 \mu \mathrm{g}$ Se plant ${ }^{-1}$ selenite, selenium urea or imidoselenocarbamate [106]) and basil (30 $\mathrm{mg} \mathrm{Se} \mathrm{L}^{-1}$ or higher) [117].

An increase in carotenoids in basil (treated with concentrations from 30 to $120 \mathrm{mg} \mathrm{Se} \mathrm{L}^{-1}$ ) [117], and of chlorophylls in spinach (treated with $1 \mathrm{mg} \mathrm{Se}^{-1}$ ) [115] have also been detected.

The effect of Se on nitrogen metabolism is not clear. Ríos et al. [118] found a reduced nitrate content in Se-treated lettuce and basil plants, respectively, whereas no effects were detected in chicory [37], spinach [104], and chard [105].

A longer shelf life and preserved quality, in association with lower rates of ethylene biosynthesis have been observed in lettuce and chicory $[37,98]$. In addition, in senescing lettuce plants, Se has been found to increase stress tolerance by preventing the decrease in tocopherol concentration and by increasing the activity of superoxide dismutase (SOD) [27].

Table 2 summarizes the main effects induced by selenium in leafy vegetables. 
Table 2. Main effects of selenium (Se) treatments on leafy vegetables.

\begin{tabular}{|c|c|c|c|c|c|c|c|c|}
\hline Plant Species & Biomass & $\begin{array}{l}\text { Oxidative } \\
\text { Markers }\end{array}$ & $\begin{array}{l}\text { Antioxidant } \\
\text { Enzymes }\end{array}$ & $\begin{array}{l}\text { Antioxidant } \\
\text { Compounds }\end{array}$ & $\begin{array}{l}\text { Photosynthetic } \\
\text { Pigments }\end{array}$ & Nitrate Content & $\begin{array}{l}\text { Ethylene } \\
\text { Production }\end{array}$ & Reference \\
\hline Ocimum basilicum L. & none & & & none & & & & Barátová et al. [93] \\
\hline Lactuca sativa $\mathrm{L}$. & $\begin{array}{l}\text { decrease at } \\
\text { high [Se] }\end{array}$ & & & & & & & Businelli et al. [109] \\
\hline Lactuca sativa L. var. Acephala & none & & & & & & decrease & Diaz et al. [98] \\
\hline Chicorium intybus L. & none & & & & & & decrease & Diaz et al. [98] \\
\hline Spinacia oleracea L. & none & & & & & none & & Ferrarese et al. [104] \\
\hline Ocimum basilicum $\mathrm{L}$. & none & improve & & increase & none & & & Hawrylak-Nowak [91] \\
\hline Lactuca sativa L. cv. Justyna & none & improve & & & $\begin{array}{l}\text { decrease at } \\
\text { high [Se] }\end{array}$ & & & Hawrylak-Nowak [116] \\
\hline Beta vulgaris subsp. Vulgaris L. & $\begin{array}{l}\text { not determined } \\
\text { (n.d). }\end{array}$ & & & & & none & & Hernández-Castro et al. [105] \\
\hline Chicorium intybus L. & none & & & & & & decrease & Malorgio et al. [37] \\
\hline Lactuca sativa L. var. Acephala & none & & & & none & none & decrease & Malorgio et al. [37] \\
\hline Ocimum basilicum L. & none & & & none & & & & Mezeyová et al. [94] \\
\hline Ocimum basilicum $\mathrm{L}$. & n.d. & & & increase & $\begin{array}{l}\text { decrease at } \\
\text { high [Se] }\end{array}$ & & & Oraghi Ardebili et al. [117] \\
\hline Lactuca sativa L. var. Acephala & none & & & & & & & Pezzarossa et al. [108] \\
\hline Lactuca sativa L. cv. Vera & none & & increase & & & & & Ramos et al. [102] \\
\hline Lactuca sativa L. cv. Philipus & $\begin{array}{l}\text { decrease at } \\
\text { high [Se] }\end{array}$ & & increase & increase & & & & Ríos et al. [113] \\
\hline Lactuca sativa L. cv. Philipus & $\begin{array}{c}\text { decrease at } \\
\text { high [Se] }\end{array}$ & & increase & & & & & Ríos et al. [111] \\
\hline Lactuca sativa L. cv. Philipus & $\begin{array}{l}\text { decrease at } \\
\text { high [Se] }\end{array}$ & & & & & decrease & & Ríos et al. [118] \\
\hline Lactuca sativa L. cv. Capitata & none & $\begin{array}{l}\text { none or } \\
\text { decrease }\end{array}$ & & & decrease & & & $\begin{array}{c}\text { Goicoechea et al.; } \\
\text { Sanmartín et al. [106,107] }\end{array}$ \\
\hline Spinacia oleracea L. & none & & & increase & increase & & & Saffaryazdi et al. [115] \\
\hline Spinacia oleracea $\mathrm{L}$. & none & & & & & & & Zhu et al. [110] \\
\hline
\end{tabular}




\section{Selenium Enrichment of Fruit Crops: Effects on Yield, Quality and Senescence}

Due to the antioxidant capacity of Se and its influence on ethylene biosynthesis, several experiments have been conducted to study the effects of Se biofortification on fruit quality and postharvest. In tomato (Solanum lycopersicon L.) selenium, as sodium selenate, has been added to nutrient solutions $[39,41,45,95,109,119,120]$ or given to plants by foliar application [121]. Only a few studies have been conducted on the Se-enrichment of fruit trees. Peaches (Prunus persica Batch) and pears (Pyrus communis L.) [40] were sprayed with selenate solution, table grapes (Vitis vinifera L.) [96] were sprayed with organic selenium, and pears (Pyrus bretschneideri cv. 'Huangguan'), grapes (Vitis vinifera, cv. 'Kyoho'), and peaches (Prunus persica, cv. 'Jinliuzaohong') were sprayed with amino acid-chelated selenium solution.

Table 3 summarizes the various studies on the Se enrichment of fruit crops.

Table 3. Selenium (Se) accumulation in fruit in relation to the concentration, the chemical form of Se supplemented to plants, and the method of Se supplementation.

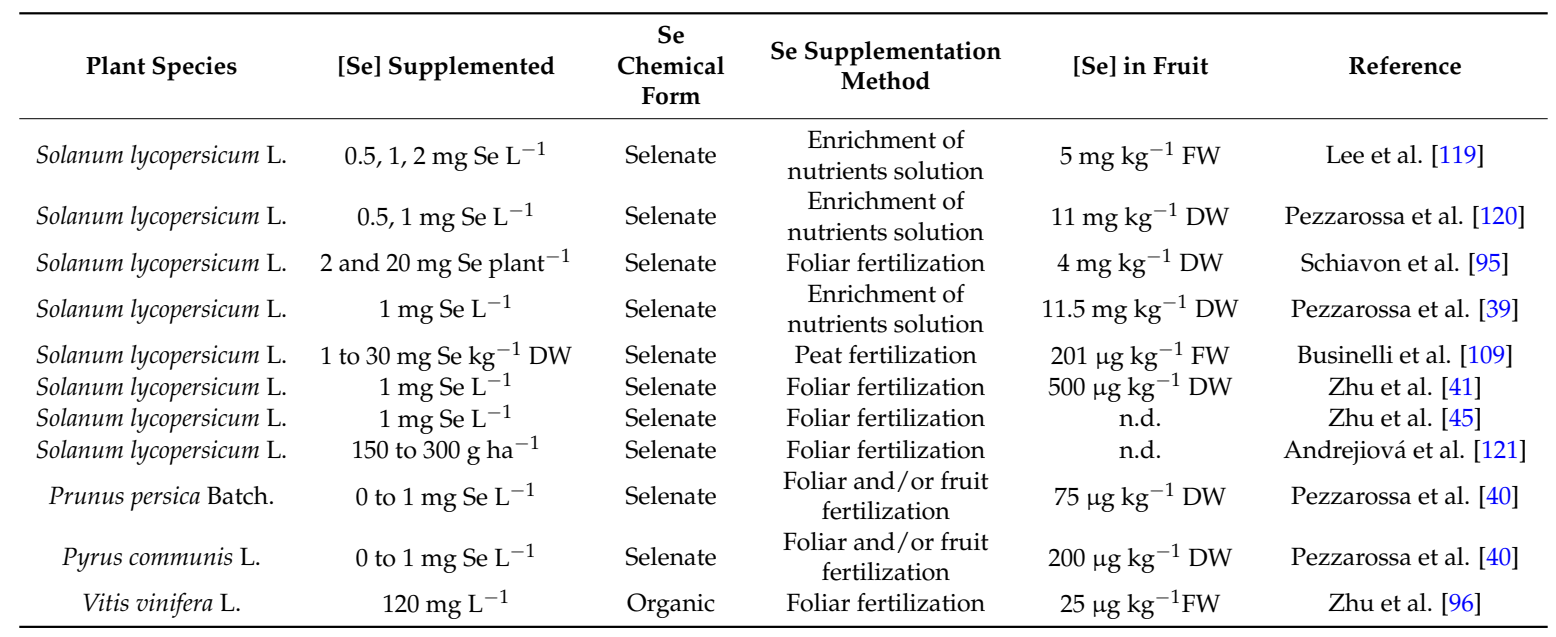

The addition of Se has been found to increase the Se concentration in the fruits and leaves of the treated plants of both tomato $[39,41,45,95,109,119,120]$ and fruit trees $[40,96]$, without affecting the yield.

Evidence of the positive effects of Se on the quality parameters of tomato fruit has been reported, such as soluble solid content [44,45,119], titrable acidity [44,119], glucose, fructose, and total sugar content [119], and firmness [44]. Se also positively affects the soluble solid content in peach and pear [40], glucose, fructose, organic acid and protein contents in grape [96]. In addition, during storage, Se delayed the decline of firmness $[40,44]$ and titrable acidity, as well as weight loss in tomato fruits [44]. In tomato fruits, Se may also induce an increased content of pigments and of antioxidant compounds $[39,45,95,120,121]$.

An increased net photosynthetic rate and a decreased stomatal conductance and transpiration rate were detected in pears, grapes, and peach foliar sprayed with amino acid-chelated selenium [122].

Treatments with Se showed a positive effect in improving the oxidative status of fruit and in delaying tomato fruit ripening, thus positively affecting the post-harvest shelf-life of fruit without negatively affecting the quality $[44,45,120]$. Se may increase the antioxidant enzyme activity $[45,109]$ and decrease various reactive oxygen species during storage [45]. Experiments conducted by Pezzarossa et al. [39] found a delay in the onset of fruit ripening in Se-enriched tomato, which also showed a reduced rate in color change, and an earlier harvesting of control plants compared to Se-treated plants. The delay in fruit ripening may depend on a reduced ethylene production. This reduction could be due to the higher cellular concentration of selenomethionine (Se-Met) than methionine (Met), which is a precursor of ethylene in the ethylene biosynthesis pathway [23,123]. 
Another hypothesis regards the genes of the enzymes involved in the ethylene biosynthesis pathway. In this pathway, the conversion of S-adenosyl methionine to 1-Aminocyclopropane-1-carboxylic acid (ACC) is catalyzed by the enzyme ACC synthase (ACS). The ACC is converted into ethylene by ACC oxidase (ACO) [123]. Four genes belong to the ACO gene family; amongst them, ACO1, is predominantly expressed in tomato fruit [124], while ACS2 and ACS4, primarily govern the ethylene production of system 2 during ripening [125]. Zhu et al. [45] found that Se can suppress the transcription of $A C O 1, A C S 2$ and $A C S 4$, thus reducing ethylene production in tomato fruits.

Se may have an indirect positive effect on the post-harvest storage of vegetables by reducing germination and the mycelial growth of some harmful fungi such as Botrytis cinerea $[41,44]$ and Pennicillium expansum [126]. Botrytis cinerea causes gray mold decay, one of the main pre- and post-harvest diseases in fruit and vegetables [127,128], leading to economic losses [129,130]. Se also counteracts infections by Alternari brassicola and Fusarium sp. and enhances resistance to fungal diseases [131], for example reducing the damage due to Fusarium wilt infection in tomato [132]. In addition, high Se concentrations in plant tissues may have a positive effect by reducing invertebrate herbivory damage [131]. Table 4 summarizes the main effects induced by selenium in fruit crops. 
Table 4. Main effects of selenium (Se) treatments on fruit crops.

\begin{tabular}{|c|c|c|c|c|c|c|c|}
\hline Plant Species & Biomass & $\begin{array}{c}\text { Reactive Oxigen } \\
\text { Species (ROS) }\end{array}$ & $\begin{array}{c}\text { Antioxidant } \\
\text { Enzymes }\end{array}$ & $\begin{array}{l}\text { Ethylene } \\
\text { Production }\end{array}$ & $\begin{array}{l}\text { Qualitative } \\
\text { Parameters }\end{array}$ & $\begin{array}{c}\text { Post-Harvest } \\
\text { Quality }\end{array}$ & Reference \\
\hline Solanum. lycopersicum L. & none & & increase & & & & Businelli et al. [109] \\
\hline Solanum. lycopersicum L. & increase & & & & increase & & Lee et al. [119] \\
\hline Solanum. lycopersicum L. & none & & & decrease & & & Pezzarossa et al. [120] \\
\hline Prunus. persica Batch. & none & & & & increase & increase & Pezzarossa et al. [40] \\
\hline Pyrus. communis L. & none & & & & increase & increase & Pezzarossa et al. [40] \\
\hline Solanum. lycopersicum L. & none & & & & & & Pezzarossa et al. [39] \\
\hline Solanum. lycopersicum L. & none & & & & & & Schiavon et al. [95] \\
\hline Solanum. lycopersicum L. & n.d. & & & & increase & increase & Zhu et al. [41] \\
\hline Solanum. lycopersicum L. & n.d. & decrease & increase & decrease & & & Zhu et al. [45] \\
\hline Solanum. lycopersicum L. & n.d. & & & & increase & & Andrejiová et al. [121] \\
\hline Vitis. vinifera L. & n.d. & & & & increase & & Zhu et al. [96] \\
\hline
\end{tabular}


In conclusion, biofortified food with selenium can address Se deficiencies in humans, thus increasing the amount of selenium in the diet and preventing the risks of excess Se intake which mineral supplements can induce. In horticultural crops, selenium has potential benefits in terms of storage and shelf-life. In fruit, Se may modulate the ripening process, probably through its antioxidant and anti-senescence properties with beneficial effects in terms of post-harvest commercial life, and greater benefits for human health. Further studies are needed in order to fully understand the molecular and biochemical mechanisms directly or indirectly affected by selenium in fruit tissues at ripening and during the postharvest phase.

Acknowledgments: The research has been supported by institutional funds of National Research Council.

Author Contributions: The Authors contributed equally to this work.

Conflicts of Interest: The authors declare no conflict of interest.

\section{References}

1. Birringer, M.; Pilawa, S.; Flohé, L. Trends in selenium biochemistry. Nat. Prod. Rep. 2002, 19, 693-718. [CrossRef] [PubMed]

2. Tapiero, H.; Townsend, D.M.; Tew, K.D. The antioxidant role of selenium and seleno-compounds. Biomed. Pharmacother. 2003, 57, 134-144. [CrossRef]

3. Rotruck, J.T.; Pope, A.L.; Ganther, H.E.; Swanson, A.B.; Hafeman, D.G.; Hoekstra, W.G. Selenium: Biochemical Role as a Component of Glutathione Peroxidase. Science 1973, 179, 588-590. [CrossRef] [PubMed]

4. Ursini, F.; Bindoli, A. The role of selenium peroxidases in the protection against oxidative damage of membranes. Chem. Phys. Lipids 1987, 44, 255-276. [CrossRef]

5. Arthur, J.R.; Nicol, F.; Beckett, G.J. Selenium deficiency, thyroid hormone metabolism, and thyroid hormone deiodinases. Am. J. Clin. Nutr. 1993, 57, 236S-239S. [PubMed]

6. Gladyshev, V.N.; Stadtman, T.C.; Hatfield, D.L.; Jeang, K.T. Levels of major selenoproteins in T cells decrease during HIV infection and low molecular mass selenium compounds increase. Proc. Natl. Acad. Sci. USA 1999, 96, 835-839. [CrossRef] [PubMed]

7. Cabaraux, J.-F.; Hornick, J.-L.; Schoonheere, N.; Istasse, L.; Dufrasne, I. Effects of selenium enriched fertilizers on Se content in feedstuffs and on the selenium status in a beef cattle herd. In Proceedings of the British Society of Animal Science, York, UK, 27-29 March 2006. Available online: http:/ /orbi.ulg.ac.be/handle/ 2268/35407 (accessed on 30 March 2017).

8. Suttle, N. Mineral Nutrition of Livestock, Hulbert, S., Hill, K., Eds.; 4th ed.; CABI: Wallingford, WC, USA, 2010. [CrossRef]

9. Shamberger, R.J. Selenium in human health and disease. Proceedings of a Nordic Symposium of Mineral Elements 80, Helsinki-Espoo, Finland, 9-11 December 1980; Mineral Elements 80: Helsinki, Finland, 1981.; pp. 501-509.

10. Rayman, M.P. Selenium and human health. Lancet 2012, 379, 1256-1268. [CrossRef]

11. Hamilton, S.J. Review of selenium toxicity in the aquatic food chain. Sci. Total Environ. 2004, 326, 1-31. [CrossRef] [PubMed]

12. Krinsky, N.; Beecher, G.R.; Burk, R.F.; Chan, A.C.; Erdman, J.W.; Jacob, R.A.; Jialal, I.; Kolonel, L.N.; Marshall, J.R.; Taylor Mayne, P.R.L.; et al. Dietary reference intakes for vitamin C, vitamin E, selenium, and carotenoids. In Institute of Medicine; The National Academies Press: Washington, DC, USA, 2000. Available online: https:/ /www.nap.edu/catalog/9810/dietary-reference-intakes-for-vitamin-c-vitamine-selenium-and-carotenoids (accessed on 30 March 2017).

13. Combs, G.F., Jr. The search for the nutritional role of selenium: A success story in poultry nutrition. Feed Manag. 1980. ISSN: 0014-956X.

14. Yang, G.; Wang, S.; Zhou, R.; Sun, S. Endemic selenium intoxication of humans in China. Am. J. Clin. Nutr. 1983, 37, 872-881. [CrossRef]

15. Raisbeck, M.F. Selenosis. Vet. Clin. North Am. Food Anim. Pract. 2000, 16, 465-480. [CrossRef] 
16. Dhillon, K.S.; Dhillon, S.K. Quality of underground water and its contribution towards selenium enrichment of the soil-plant system for a seleniferous region of northwest India. J. Hydrol. 2003, 272, 120-130. [CrossRef]

17. Hartikainen, H.; Xue, T.; Piironen, V. Selenium as an anti-oxidant and pro-oxidant in ryegrass. Plant Soil 2000, 225, 193-200. [CrossRef]

18. Terry, N.; Zayed, A.M.; Souza, M.P. De; Tarun, A.S. Selenium in higher plants. Annu. Rev. Plant Physiol. Plant Mol. Biol. 2000, 51, 401-432. [CrossRef] [PubMed]

19. Djanaguiraman, M.; Devi, D.D.; Shanker, A.K.; Sheeba, J.A.; Bangarusamy, U. Selenium-An antioxidative protectant in soybean during senescence. Plant Soil 2005, 272, 77-86. [CrossRef]

20. Zhu, Y.G.; Pilon-Smits, E.A. H.; Zhao, F.J.; Williams, P.N.; Meharg, A.A. Selenium in higher plants: understanding mechanisms for biofortification and phytoremediation. Trends Plant Sci. 2009, 14, 436-442. [CrossRef] [PubMed]

21. Bañuelos, G.S.; Meek, D.W. Accumulation of Selenium in Plants Grown on Selenium-Treated Soil. J. Environ. Qual. 1990, 19, 772. [CrossRef]

22. Ellis, D.R.; Salt, D.E. Plants, selenium and human health. Curr. Opin. Plant Biol. 2003, 6, 273-279. [CrossRef]

23. Brown, T.A.; Shrift, A. Selenium: Toxicity and Tolerance in Higher Plants. Biol. Rev. 1982, 57, 59-84. [CrossRef]

24. White, P.J.; Bowen, H.C.; Parmaguru, P.; Fritz, M.; Spracklen, W.P.; Spiby, R.E.; Meacham, M.C.; Mead, A.; Harriman, M.; Trueman, L.J.; et al. Interactions between selenium and sulphur nutrition in Arabidopsis thaliana. J. Exp. Bot. 2004, 55, 1927-1937. [CrossRef] [PubMed]

25. Thavarajah, D.; Ruszkowski, J.; Vandenberg, A. High potential for selenium biofortification of lentils (Lens culinaris L.). J. Agric. Food Chem. 2008, 56, 10747-10753. [CrossRef] [PubMed]

26. Navarro-Alarcon, M.; Cabrera-Vique, C. Selenium in food and the human body: A review. Sci. Total Environ. 2008, 400, 115-141. [CrossRef] [PubMed]

27. Xue, T.; Hartikainen, H.; Piironen, V. Antioxidative and growth-promoting effect of selenium on senescing lettuce. Plant Soil 2001, 237, 55-61. [CrossRef]

28. Hu, Q.; Xu, J.; Pang, G. Effect of selenium on the yield and quality of green tea leaves harvested in early spring. J. Agric. Food Chem. 2003, 51, 3379-3381. [CrossRef] [PubMed]

29. Turakainen, M.; Hartikainen, H.; Ekholm, P.; Seppänen, M.M. Distribution of selenium in different biochemical fractions and raw darkening degree of potato (Solanum tuberosum L.) tubers supplemented with selenate. J. Agric. Food Chem. 2006, 54, 8617-8622. [CrossRef] [PubMed]

30. Schiavon, M.; Pilon-Smits, E.A.H. Selenium Biofortification and Phytoremediation Phytotechnologies: A Review. J. Environ. Qual. 2017, 46, 10. [CrossRef] [PubMed]

31. Seppänen, M.; Turakainen, M.; Hartikainen, H. Selenium effects on oxidative stress in potato. Plant Sci. 2003, 165, 311-319. [CrossRef]

32. Cartes, P.; Gianfreda, L.; Mora, M.L. Uptake of selenium and its antioxidant activity in ryegrass when applied as selenate and selenite forms. Plant Soil 2005, 276, 359-367. [CrossRef]

33. De la Luz Mora, M.; Pinilla, L.; Rosas, A.; Cartes, P. Selenium uptake and its influence on the antioxidative system of white clover as affected by lime and phosphorus fertilization. Plant Soil 2008, 303, 139-149. [CrossRef]

34. Carvalho, K.M.; Gallardo-Williams, M.T.; Benson, R.F.; Martin, D.F. Effects of selenium supplementation on four agricultural crops. J. Agric. Food Chem. 2003, 51, 704-709. [CrossRef] [PubMed]

35. Song, Y.R.; Jiang, X.G.; Peng, S.F.; Li, F.C.; Liu, J.; Chen, D. Effect of selenium content on the quality and functional components of selenium-riched Camellia oleifera oil. J. Chin. Inst. Food Sci. Technol. 2015, 15, 142-149. [CrossRef]

36. Lv, J.; Wu, J.; Zuo, J.; Fan, L.; Shi, J.; Gao, L.; Li, M.; Wang, Q. Effect of Se treatment on the volatile compounds in broccoli. Food Chem. 2017, 216, 225-233. [CrossRef] [PubMed]

37. Malorgio, F.; Diaz, K.E.; Ferrante, A.; Mensuali-Sodi, A.; Pezzarossa, B. Effects of selenium addition on minimally processed leafy vegetables grown in a floating system. J. Sci. Food Agric. 2009, 89, 2243-2251. [CrossRef]

38. Pezzarossa, B.; Piccotino, D.; Shennan, C.; Malorgio, F. Uptake and distribution of selenium in tomato plants as affected by genotype and sulphate supply. J. Plant Nutr. 1999, 22, 1613-1635. [CrossRef] 
39. Pezzarossa, B.; Rosellini, I.; Borghesi, E.; Tonutti, P.; Malorgio, F. Effects of Se-enrichment on yield, fruit composition and ripening of tomato (Solanum lycopersicum) plants grown in hydroponics. Sci. Hortic. (Amsterdam) 2014, 165, 106-110. [CrossRef]

40. Pezzarossa, B.; Remorini, D.; Gentile, M.L.; Massai, R. Effects of foliar and fruit addition of sodium selenate on selenium accumulation and fruit quality. J. Sci. Food Agric. 2012, 92, 781-786. [CrossRef] [PubMed]

41. Wu, Z.; Yin, X.; Bañuelos, G.S.; Lin, Z.Q.; Zhu, Z.; Liu, Y.; Yuan, L.; Li, M. Effect of selenium on control of postharvest gray mold of tomato fruit and the possible mechanisms involved. Front. Microbiol. 2016, 6, 1-11. [CrossRef] [PubMed]

42. Djanaguiraman, M.; Prasad, P.V.V.; Seppanen, M. Selenium protects sorghum leaves from oxidative damage under high temperature stress by enhancing antioxidant defense system. Plant Physiol. Biochem. 2010, 48, 999-1007. [CrossRef] [PubMed]

43. Hasanuzzaman, M.; Fujita, M. Selenium pretreatment upregulates the antioxidant defense and methylglyoxal detoxification system and confers enhanced tolerance to drought stress in rapeseed seedlings. Biol. Trace Elem. Res. 2011, 143, 1758-1776. [CrossRef] [PubMed]

44. Zhu, Z.; Chen, Y.; Zhang, X.; Li, M. Effect of foliar treatment of sodium selenate on postharvest decay and quality of tomato fruits. Sci. Hortic. (Amsterdam) 2016, 198, 304-310. [CrossRef]

45. Zhu, Z.; Chen, Y.; Shi, G.; Zhang, X. Selenium delays tomato fruit ripening by inhibiting ethylene biosynthesis and enhancing the antioxidant defense system. Food Chem. 2017, 219, 179-184. [CrossRef] [PubMed]

46. Rayman, M.P. The use of high-selenium yeast to raise selenium status: How does it measure up? Br. J. Nutr. 2004, 92, 557-573. [CrossRef] [PubMed]

47. Rayman, M.P. Food-chain selenium and human health: emphasis on intake. Br. J. Nutr. 2008, 100, $254-268$. [CrossRef] [PubMed]

48. Broadley, M.R.; White, P.J.; Bryson, R.J.; Meacham, M.C.; Bowen, H.C.; Johnson, S.E.; Hawkesford, M.J.; McGrath, S.P.; Zhao, F.-J.; Breward, N.; et al. Biofortification of UK food crops with selenium. Proc. Nutr. Soc. 2006, 65, 169-181. [CrossRef] [PubMed]

49. Broadley, M.R.; Alcock, J.; Alford, J.; Cartwright, P.; Foot, I.; Fairweather-Tait, S.J.; Hart, D.J.; Hurst, R.; Knott, P.; McGrath, S.P.; et al. Selenium biofortification of high-yielding winter wheat (Triticum aestivum L.) by liquid or granular Se fertilisation. Plant Soil 2010, 332, 5-18. [CrossRef]

50. Fairweather-Tait, S.J.; Bao, Y.; Broadley, M.R.; Collings, R.; Ford, D.; Hesketh, J.E.; Hurst, R. Selenium in human health and disease. Antioxid. Redox Signal. 2011, 14, 1337-1383. [CrossRef] [PubMed]

51. Thomson, C.D. Selenium and iodine intakes and status in New Zealand and Australia. Br. J. Nutr. 2004, 91, 661-672. [CrossRef] [PubMed]

52. Williams, P.N.; Lombi, E.; Sun, G.X.; Scheckel, K.; Zhu, Y.G.; Feng, X.; Zhu, J.; Carey, A.M.; Adomako, E.; Lawgali, Y.; et al. Selenium characterization in the global rice supply chain. Environ. Sci. Technol. 2009, 43, 6024-6030. [CrossRef] [PubMed]

53. Johnson, C.C.; Fordyce, F.M.; Rayman, M.P. Factors controlling the distribution of selenium in the environment and their impact on health and nutrition. Proc. Nutr. Soc. 2010, 69, 119-132. [CrossRef] [PubMed]

54. Benemariya, H.; Robberecht, H.; Deelstra, H. Daily dietary intake of copper, zinc and selenium by different population groups in Burundi, Africa. Sci. Total Environ. 1993, 136, 49-76. [CrossRef]

55. Calvo, M.S.; Whiting, S.J. Survey of current vitamin D food fortification practices in the United States and Canada. J. Steroid Biochem. Mol. Biol. 2013, 136, 211-213. [CrossRef] [PubMed]

56. Gómez-Galera, S.; Rojas, E.; Sudhakar, D.; Zhu, C.; Pelacho, A.M.; Capell, T.; Christou, P. Critical evaluation of strategies for mineral fortification of staple food crops. Transgenic Res. 2010, 19, 165-180. [CrossRef] [PubMed]

57. Bañuelos, G.S.; Lin, Z.Q. Use and Development of Biofortified Agricultural Products; CRC Press: Boca Raton, FL, USA, 2009. [CrossRef]

58. Carvalho, S.M. P.; Vasconcelos, M.W. Producing more with less: Strategies and novel technologies for plant-based food biofortification. Food Res. Int. 2013, 54, 961-971. [CrossRef]

59. Hefferon, K.L. Nutritionally enhanced food crops; progress and perspectives. Int. J. Mol. Sci. 2015, 16, 3895-3914. [CrossRef] [PubMed] 
60. Díaz-Gómez, J.; Twyman, R.M.; Zhu, C.; Farré, G.; Serrano, J.C.E.; Portero-Otin, M.; Muñoz, P.; Sandmann, G.; Capell, T.; Christou, P.; et al. Biofortification of crops with nutrients: Factors affecting utilization and storage. Curr. Opin. Biotechnol. 2016, 44, 115-123. [CrossRef] [PubMed]

61. Hart, D.J.; Fairweather-Tait, S.J.; Broadley, M.R.; Dickinson, S.J.; Foot, I.; Knott, P.; McGrath, S.P.; Mowat, H.; Norman, K.; Scott, P.R.; et al. Selenium concentration and speciation in biofortified flour and bread: Retention of selenium during grain biofortification, processing and production of Se-enriched food. Food Chem. 2011, 126, 1771-1778. [CrossRef] [PubMed]

62. White, P.J.; Broadley, M.R. Biofortification of crops with seven mineral elements often lacking in human diets - Iron, zinc, copper, calcium, magnesium, selenium and iodine. New Phytol. 2009, 182, 49-84. [CrossRef] [PubMed]

63. Landini, M.; Gonzali, S.; Perata, P. Iodine biofortification in tomato. J. Plant Nutr. Soil Sci. 2011, 174, 480-486. [CrossRef]

64. Eurola, M.H.; Ekholm, P.I.; Ylinen, M.E.; Varo, P.T.; Koivistoinen, P.E. Selenium in Finnish foods after beginning the use of selenate-supplemented fertilisers. J. Sci. Food Agric. 1991, 56, 57-70. [CrossRef]

65. Poblaciones, M.J.; Rodrigo, S.; Santamaría, O.; Chen, Y.; McGrath, S.P. Agronomic selenium biofortification in Triticum durum under Mediterranean conditions: From grain to cooked pasta. Food Chem. 2014, 146, 378-384. [CrossRef] [PubMed]

66. Hawkesford, M.J.; Zhao, F.J. Strategies for increasing the selenium content of wheat. J. Cereal Sci. 2007, 46, 282-292. [CrossRef]

67. Malagoli, M.; Schiavon, M.; Dall'Acqua, S.; Pilon-Smits, E.A.H. Effects of selenium biofortification on crop nutritional quality. Front. Plant Sci. 2015, 6, 280. [CrossRef] [PubMed]

68. Zhu, Z.; Zhang, Z.; Qin, G.; Tian, S. Effects of brassinosteroids on postharvest disease and senescence of jujube fruit in storage. Postharvest Biol. Technol. 2010, 56, 50-55. [CrossRef]

69. Finley, J.W. Selenium Accumulation in Plant Foods. Nutr. Rev. 2005, 63, 196-202. [CrossRef] [PubMed]

70. Hartikainen, H. Biogeochemistry of selenium and its impact on food chain quality and human health. J. Trace Elem. Med. Biol. 2005, 18, 309-318. [CrossRef] [PubMed]

71. Hurst, R.; Armah, C.N.; Dainty, J.R.; Hart, D.J.; Teucher, B.; Goldson, A.J.; Broadley, M.R.; Motley, A.K.; Fairweather-Tait, S.J. Establishing optimal selenium status: Results of a randomized, double-blind, placebo-controlled trial. Am. J. Clin. Nutr. 2010, 91, 923-931. [CrossRef] [PubMed]

72. Kotrebai, M.; Birringer, M.; Tyson, J.F.; Block, E.; Uden, P.C. Selenium speciation in enriched and natural samples by HPLC-ICP-MS and HPLC-ESI-MS with perfluorinated carboxylic acid ion-pairing agents. Analyst 2000, 125, 71-78. [CrossRef] [PubMed]

73. Ip, C.; Kotrebai, M.; Birringer, M.; Tyson, J.; Block, E.; Uden, P.C.; Lisk, D.J. Chemical speciation influences comparative activity of selenium-enriched garlic and yeast in mammary cancer prevention. J. Agric. Food Chem. 2000, 48. [CrossRef]

74. Finley, J.W.; Ip, C.; Lisk, D.J.; Davis, C.D.; Hintze, K.J.; Whanger, P.D. Cancer-protective properties of high-Selenium broccoli. J. Agric. Food Chem. 2001, 49, 2679-2683. [CrossRef] [PubMed]

75. Mechora, Š.; Stibilj, V.; Radešček, T.; Gaberščik, A.; Germ, M. Impact of se (VI) fertilization on se concentration in different parts of red cabbage plants. J. Food Agric. Environ. 2011, 9, 357-361.

76. Mechora, Š.; Stibilj, V.; Kreft, I.; Germ, M. The Physiology and Biochemical Tolerance of Cabbage to Se (VI) Addition to the Soil and by Foliar Spraying. J. Plant Nutr. 2014, 37, 2157-2169. [CrossRef]

77. Premarathna, L.; McLaughlin, M.J.; Kirby, J.K.; Hettiarachchi, G.M.; Stacey, S.; Chittleborough, D.J. Selenate-enriched urea granules are a highly effective fertilizer for selenium biofortification of paddy rice grain. J. Agric. Food Chem. 2012, 60, 6037-6044. [CrossRef] [PubMed]

78. Fernandes, K.F.M.; Berton, R.S.; Coscione, A.R. Selenium biofortification of rice and radish: Effect of soil texture and efficiency of two extractants. Plant Soil Environ. 2014, 60, 105-110.

79. Chilimba, A.D.C.; Young, S.D.; Black, C.R.; Meacham, M.C.; Lammel, J.; Broadley, M.R. Agronomic biofortification of maize with selenium (Se) in Malawi. F. Crop. Res. 2012, 125, 118-128. [CrossRef]

80. Bañuelos, G.S.; Arroyo, I.; Pickering, I.J.; Yang, S.I.; Freeman, J.L. Selenium biofortification of broccoli and carrots grown in soil amended with Se-enriched hyperaccumulator Stanleya pinnata. Food Chem. 2015, 166, 603-608. [CrossRef] [PubMed] 
81. Freeman, J.L.; Bañuelos, G.S. Selection of salt and boron tolerant selenium hyperaccumulator Stanleya pinnata genotypes and characterization of Se phytoremediation from agricultural drainage sediments. Environ. Sci. Technol. 2011, 45, 9703-9710. [CrossRef] [PubMed]

82. Bañuelos, G.S.; Da Roche, J.; Robinson, J. Developing selenium-enriched animal feed and biofuel from canola planted for managing Se-laden drainage waters in the westside of central California. Int. J. Phytoremediat. 2010, 12, 243-254. [CrossRef] [PubMed]

83. Poggi, V.; Arcioni, A.; Filippini, P.; Pifferi, P.G. Foliar application of selenite and selenate to potato (Solanum tuberosum): Effect of a ligand agent on selenium content of tubers. J. Agric. Food Chem. 2000, 48, 4749-4751. [CrossRef] [PubMed]

84. Chen, L.; Yang, F.; Xu, J.; Hu, Y.; Hu, Q.; Zhang, Y.; Pan, G. Determination of selenium concentration of rice in China and effect of fertilization of selenite and selenate on selenium content of rice. J. Agric. Food Chem. 2002, 50, 5128-5130. [CrossRef] [PubMed]

85. Yang, F.; Chen, L.; Hu, Q.; Pan, G. Effect of the application of selenium on selenium content of soybean and its products. Biol. Trace Elem. Res. 2003, 93, 249-256. [CrossRef]

86. Stibilj, V.; Kreft, I.; Smrkolj, P.; Osvald, J. Enhanced selenium content in buckwheat (Fagopyrum esculentum Moench) and pumpkin (Cucurbita pepo L.) seeds by foliar fertilisation. Eur. Food Res. Technol. 2004, 219, 142-144. [CrossRef]

87. Smrkolj, P.; Pograjc, L.; Hlastan-Ribič, C.; Stibilj, V. Selenium content in selected Slovenian foodstuffs and estimated daily intakes of selenium. Food Chem. 2005, 90, 691-697. [CrossRef]

88. Kápolna, E.; Hillestrøm, P.R.; Laursen, K.H.; Husted, S.; Larsen, E.H. Effect of foliar application of selenium on its uptake and speciation in carrot. Food Chem. 2009, 115, 1357-1363. [CrossRef]

89. Šindelářová, K.; Száková, J.; Tremlová, J.; Mestek, O.; Praus, L.; Kaňa, A.; Najmanová, J.; Tlustoš, P. The response of broccoli (Brassica oleracea convar. italica) varieties on foliar application of selenium: Uptake, translocation, and speciation. Food Addit. Contam. Part A. Chem. Anal. Control. Expo. Risk Assess. 2015, 32, 2027-2038. [CrossRef]

90. Schiavon, M.; Berto, C.; Malagoli, M.; Trentin, A.; Sambo, P.; Dall'Acqua, S.; Pilon-Smits, E.A.H. Selenium Biofortification in Radish Enhances Nutritional Quality via Accumulation of Methyl-Selenocysteine and Promotion of Transcripts and Metabolites Related to Glucosinolates, Phenolics, and Amino Acids. Front. Plant Sci. 2016, 7, 1371. [CrossRef] [PubMed]

91. Hawrylak-Nowak, B. Enhanced selenium content in sweet basil (Ocimum basilicum L.) by foliar fertilization. Veg. Crop. Res. Bull. 2008, 69, 63-72. [CrossRef]

92. Kopsell, D.A.; Sams, C.E.; Barickman, T.C.; Deyton, D.E.; Kopsell, D.E. Selenization of basil and cilantro through foliar applications of selenate-selenium and selenite-selenium. HortScience 2009, 44, 438-442.

93. Barátová, S.; Mezeyova, I.; Hegedusová, A.; Andrejiová, A. Impact of biofortification, variety and cutting on chosen qualitative characteristic of basil (Ocimum basilicum L.). Acta Fytotech. Zootech. 2015, 18, 71-75. [CrossRef]

94. Mezeyová, I.; Hegedûsová, A.; Andrejiová, A.; Hegedûs, O.; Golian, M. Phytomass and content of essential oils in Ocimum basilicum after foliar treatment with selenium. J. Int. Sci. Publ. 2016, 4, $19-27$.

95. Schiavon, M.; Dall'Acqua, S.; Mietto, A.; Pilon-Smits, E.A.H.; Sambo, P.; Masi, A.; Malagoli, M. Selenium fertilization alters the chemical composition and antioxidant constituents of tomato (Solanum lycopersicon L.). J. Agric. Food Chem. 2013, 61, 10542-10554. [CrossRef] [PubMed]

96. Zhu, S.; Liang, Y.; Gao, D.; An, X.; Kong, F. Spraying foliar selenium fertilizer on quality of table grape (Vitis vinifera L.) from different source varieties. Sci. Hortic. (Amsterdam) 2017, 218, 87-94. [CrossRef]

97. Germ, M.; Stibilj, V.; Osvald, J.J.; Kreft, I. Effect of selenium foliar application on chicory (Cichorium intybus L.). J. Agric. Food Chem. 2007, 55, 795-798. [CrossRef] [PubMed]

98. Diaz, K.E.; Mensuali-Sodi, A.; Serra, G.; Malorgio, F.; Tognoni, F.; Ferrante, A.; Pezzarossa, B. Effect of selenium addition on phenylalanine ammonia lyase (PAL) activity and ethylene production in leafy vegetables. Adv. Plant Ethyl. Res. 2007, 207-209. [CrossRef]

99. MacLeod, J.; Gupta, U.C.; Milburn, P.; Sanderson, J.B. Selenium concentration in plant material, drainage and surface water as influenced by Se applied to barley foliage in a barley-red clover-potato rotation. Can. J. Soil Sci. 1998, 78, 685-688. [CrossRef] 
100. Ožbolt, L.; Kreft, S.; Kreft, I.; Germ, M.; Stibilj, V. Distribution of selenium and phenolics in buckwheat plants grown from seeds soaked in Se solution and under different levels of UV-B radiation. Food Chem. 2008, 110, 691-696. [CrossRef]

101. Nawaz, F.; Ashraf, M.Y.; Ahmad, R.; Waraich, E.A. Selenium (Se) seed priming induced growth and biochemical changes in wheat under water deficit conditions. Biol. Trace Elem. Res. 2013, 151, 284-293. [CrossRef] [PubMed]

102. Ramos, S.J.; Faquin, V.; Guilherme, L.R.G.; Castro, E.M.; Ávila, F.W.; Carvalho, G.S.; Bastos, C.E.A.; Oliveira, C. Selenium biofortification and antioxidant activity in lettuce plants fed with selenate and selenite. Plant Soil Environ. 2010, 56, 584-588.

103. Smoleń, S.; Kowalska, I.; Sady, W. Assessment of biofortification with iodine and selenium of lettuce cultivated in the NFT hydroponic system. Sci. Hortic. (Amsterdam) 2014, 166, 9-16. [CrossRef]

104. Ferrarese, M.; Mahmoodi Sourestani, M.; Quattrini, E.; Schiavi, M.; Ferrante, A. Biofortification of Spinach Plants Applying Selenium in the Nutrient Solution of Floating System. Veg. Crop. Res. Bull. 2012, 76, 127-136. [CrossRef]

105. Hernández-Castro, E.; Trejo-Téllez, L.; Gómez-Merino, F.; Rodríguez-Mendoza, M.; Sánchez-García, P.; Robledo-Paz, A. Bioaccumulation of iron, selenium, nitrate, and proteins in chard shoots. J. Soil Sci. Plant Nutr. 2015, 15, 694-710. [CrossRef]

106. Goicoechea, N.; Garmendia, I.; Fabbrin, E.G.; Bettoni, M.M.; Palop, J.A.; Sanmartín, C. Selenium fertilization and mycorrhizal technology may interfere in enhancing bioactive compounds in edible tissues of lettuces. Sci. Hortic. (Amsterdam) 2015, 195, 163-172. [CrossRef]

107. Sanmartín, C.; Garmendia, I.; Romano, B.; Díaz, M.; Palop, J.A.; Goicoechea, N. Mycorrhizal inoculation affected growth, mineral composition, proteins and sugars in lettuces biofortified with organic or inorganic selenocompounds. Sci. Hortic. 2014, 180, 40-51. [CrossRef]

108. Pezzarossa, B.; Petruzzelli, G.; Petacco, F.; Malorgio, F.; Ferri, T. Absorption of selenium by Lactuca sativa as affected by carboxymethylcellulose. Chemosphere 2007, 67, 322-329. [CrossRef] [PubMed]

109. Businelli, D.; D'Amato, R.; Onofri, A.; Tedeschini, E.; Tei, F. Se-enrichment of cucumber (Cucumis sativus L.), lettuce (Lactuca sativa L.) and tomato (Solanum lycopersicum L. Karst) through fortification in pre-transplanting. Sci. Hortic. (Amsterdam) 2015, 197, 697-704. [CrossRef]

110. Zhu, Y.G.; Huang, Y.; Hu, Y.; Liu, Y.; Christie, P. Interactions between selenium and iodine uptake by spinach (Spinacia oleracea L.) in solution culture. Plant Soil 2004, 261, 99-105. [CrossRef]

111. Ríos, J.J.; Blasco, B.; Cervilla, L.M.; Rosales, M.A.; Sanchez-Rodriguez, E.; Romero, L.; Ruiz, J.M. Production and detoxification of $\mathrm{H}_{2} \mathrm{O}_{2}$ in lettuce plants exposed to selenium. Ann. Appl. Biol. 2009, 154, 107-116. [CrossRef]

112. Blasco, B.; Rios, J.J.; Cervilla, L.M.; Sánchez-Rodríguez, E.; Rubio-Wilhelmi, M.M.; Rosales, M.A.; Ruiz, J.M.; Romero, L. Photorespiration Process and Nitrogen Metabolism in Lettuce Plants (Lactuca sativa L.): Induced Changes in Response to Iodine Biofortification. J. Plant Growth Regul. 2010, 29, 477-486. [CrossRef]

113. Ríos, J.J.; Rosales, M.A.; Blasco, B.; Cervilla, L.M.; Romero, L.; Ruiz, J.M. Biofortification of Se and induction of the antioxidant capacity in lettuce plants. Sci. Hortic. (Amsterdam). 2008, 116, 248-255. [CrossRef]

114. Ríos, J.J.; Blasco, B.; Leyva, R.; Sanchez-Rodriguez, E.; Rubio-Wilhelmi, M.M.; Romero, L.; Ruiz, J.M. Nutritional Balance Changes in Lettuce Plant Grown Under Different Doses and Forms of Selenium. J. Plant Nutr. 2013, 36, 1344-1354. [CrossRef]

115. Saffaryazdi, A.; Lahouti, M.; Ganjeali, A.; Bayat, H. Impact of Selenium Supplementation on Growth and Selenium Accumulation on Spinach (Spinacia oleracea L.) Plants. Not. Sci. Biol. 2012, 4, 95-100. [CrossRef]

116. Hawrylak-Nowak, B. Comparative effects of selenite and selenate on growth and selenium accumulation in lettuce plants under hydroponic conditions. Plant Growth Regul. 2013, 70, 149-157. [CrossRef]

117. Oraghi Ardebili, Z.; Oraghi Ardebili, N.; Jalili, S.; Safiallah, S. The modified qualities of basil plants by selenium and/or ascorbic acid. Turk. J. Botany 2015, 39, 401-407. [CrossRef]

118. Ríos, J.J.; Blasco, B.; Rosales, M.A.; Sanchez-Rodriguez, E.; Leyva, R.; Cervilla, L.M.; Romero, L.; Ruiz, J.M. Response of nitrogen metabolism in lettuce plants subjected to different doses and forms of selenium. J. Sci. Food Agric. 2010, 90, 1914-1919. [CrossRef] [PubMed]

119. Lee, G.-J.; Kang, B.-K.; Kim, T.-I.; Kim, T.-J.; Kim, J.-H. Effects of different selenium concentrations of the nutrient solution on the growth and quality of tomato fruit in hydroponics. Acta Hortic. 2007, 761, 443-448. [CrossRef] 
120. Pezzarossa, B.; Rosellini, I.; Malorgio, F.; Borghesi, E.; Tonutti, P. Effects of selenium enrichment of tomato plants on ripe fruit metabolism and composition. Acta Hortic. 2013, 247-251. [CrossRef]

121. Andrejiová, A.; Hegedûsová, A.; Mezeyová, I. Effect of genotype and selenium biofortification on content of important bioactive substances in tomato (Lycopersicon esculentum Mill.) fruits. J. Int. Sci. Publ. 2016, 4, 8-18.

122. Feng, T.; Chen, S.S.; Gao, D.Q.; Liu, G.Q.; Bai, H.X.; Li, A.; Peng, L.X.; Ren, Z.Y. Selenium improves photosynthesis and protects photosystem II in pear (Pyrus bretschneideri), grape (Vitis vinifera), and peach (Prunus persica). Photosynthetica 2015, 53, 609-612. [CrossRef]

123. Yang, S.F.; Hoffman, N.E. Ethylene biosynthesis and its regulation in higher plants. Annu. Rev. Plant Physiol. 1984, 35, 155-189. [CrossRef]

124. Barry, C.S.; Llop-Tous, M.I.; Grierson, D. The regulation of 1-aminocyclopropane-1-carboxylic acid synthase gene expression during the transition from system-1 to system-2 ethylene synthesis in tomato. Plant Physiol. 2000, 123, 979-986. [CrossRef] [PubMed]

125. Nakatsuka, A.; Murachi, S.; Okunishi, H.; Shiomi, S.; Nakano, R.; Kubo, Y.; Inaba, A. Differential expression and internal feedback regulation of 1-aminocyclopropane-1-carboxylate synthase, 1-aminocyclopropane-1-carboxylate oxidase, and ethylene receptor genes in tomato fruit during development and ripening. Plant Physiol. 1998, 118, 1295-1305. [CrossRef] [PubMed]

126. Wu, Z.; Yin, X.; Lin, Z.; Bañuelos, G.S.; Yuan, L.; Liu, Y.; Li, M. Inhibitory effect of selenium against Penicillium expansum and its possible mechanisms of action. Curr. Microbiol. 2014, 69, 192-201. [CrossRef] [PubMed]

127. Quinn, C.F.; Freeman, J.L.; Reynolds, R.J. B.; Cappa, J.J.; Fakra, S.C.; Marcus, M.A.; Lindblom, S.D.; Quinn, E.K.; Bennett, L.E.; Pilon-Smits, E.A.H.; et al. Selenium hyperaccumulation offers protection from cell disruptor herbivores. BMC Ecol. 2010, 10, 19. [CrossRef] [PubMed]

128. Youssef, K.; Roberto, S.R. Salt strategies to control Botrytis mold of "Benitaka" table grapes and to maintain fruit quality during storage. Postharvest Biol. Technol. 2014, 95, 95-102. [CrossRef]

129. Soylu, E.M.; Kurt, S..; Soylu, S. In vitro and in vivo antifungal activities of the essential oils of various plants against tomato grey mould disease agent Botrytis cinerea. Int. J. Food Microbiol. 2010, 143, 183-189. [CrossRef] [PubMed]

130. Cabot, C.; Gallego, B.; Martos, S.; Barceló, J.; Poschenrieder, C. Signal cross talk in Arabidopsis exposed to cadmium, silicon, and Botrytis cinerea. Planta 2013, 237, 337-349. [CrossRef] [PubMed]

131. Hanson, B.; Garifullina, G.F.; Lindblom, S.D.; Wangeline, A.; Ackley, A.; Kramer, K.; Norton, A.P.; Lawrence, C.B.; Pilon-Smits, E.A.H. Selenium accumulation protects Brassica juncea from invertebrate herbivory and fungal infection. New Phytol. 2003, 159, 461-469. [CrossRef]

132. Companioni, B.; Medrano, J.; Torres, J.A.; Flores, A.; Rodríguez, E.; Benavides, A. Protective action of sodium selenite against Fusarium wilt in tomato: Total protein contents, levels of phenolic compounds and changes in antioxidant potential. Acta Hortic. 2012, 947, 321-328. [CrossRef] 